\title{
タンデム翼列によるファンの高負荷化*1 Highly Loaded Fan by Using Tandem Cascade Rotor Blade
}

\author{
長谷川 裕 晃 ${ }^{* 2} \cdot$ 須 賀 信 也*3 松 岡 右 典*3 \\ Hiroaki Hasegawa, Shinya Suga and Akinori Matsuoka
}

Key Words : Engines, Fan, Tandem Cascades, High Pressure Ratio

\begin{abstract}
For axial flow compressors and fans in the aircraft engines higher pressure ratio is required in order to attain the high thrust engines. In this study, the fan with the tandem cascades was introduced to increase the fan pressure ratio. The use of tandem cascades in the fan allows savings in length and weight and therefore a compact fan could be built. The design of fan with tandem cascades and the fan testing were carried out to develop the high pressure ratio fan for the Air Turbo Ramjet (ATR) propulsion system. The ATR is a combined cycle engine which performs like a turbojet engine at subsonic speeds and a ramjet at supersonic speeds. In particular, high fan pressure ratio contributes to increase the engine thrust during subsonic flight at which the engine does not make use of ram effect. The results of the fan testing indicate that the pressure ratio of 2.2 is achieved in single stage fan.
\end{abstract}

\section{1. 緒言}

航空機用エンジンの圧縮機, ファン要素 ${ }^{1)}$ に対しては, 軽

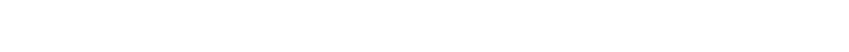
特に, 軸流圧縮機や高バイパス比ファンのファンモジュー ルでは, 圧縮機およびファン要素がエンジン全体に占める 重量，コストの割合は高い，つまり，段あたりの負荷を高 めて, 少ない段数で高い圧力比を得ることは, 軽量化に加 え部品点数削減によるコスト低減と整備性の向上を可能に する．

本研究においては, 小型軽量化と高推力化を目的とした エアーターボラム (Air Turbo Ramjet: ATR) エンジン2) 用のタンデム翼列ファンの開発を実施した ATR は, ラム ジェットとターボジェットを複合した推進システムであり， 自立発進可能で亜音速域から超音速域までの広範囲の飛行 が単一エンジンで可能である ${ }^{3,4)}$. ATR では, 外部から吸 い込んだ空気をファンにより圧縮し，ラム燃焼器入導く．し たがってファン圧力比の増加は, ラム燃焼器内の圧力を上 昇させ, 推力増加に直接影響する。特に, 亜音速域での飛 行においては，ラム圧による圧縮効果が期待できないため， ファン圧力比か推力増加に寄与する割合が高い．このため， ファンの高圧力比化により低速度飛行域からの加速におい て，十分な推力余裕をもたせることが可能になる．

タンデム翼列ファンは, 反りの大きな翼形状においても， 翼面から流れがはく離することを防止でき，効率を犠牲に せず高圧力比化が達成できる .さらに, ファンの多段化で 生じる重量等の増加を抑制することが可能となる．タンデ

\footnotetext{
*1 (C) 2003 日本航空宇宙学会

平成 14 年 1 月 11 日原稿受理

*2 防衛庁技術研究本部

*3 川崎重工業 (株)
}

么翼列を圧縮機の動翼に適用した研究 ${ }^{5,6)}$ は報告されてい るものの，低速の亜音速翼列の場合であり，遷音速翼列に タンデム翼列を適用した例は現在報告されていない，弚こ で本研究では, ATR 用のタンデム翼列ファンの設計および エアーインテークの構造を考慮し, ファンへの空気流入形 態を変化させた状態で実施したファン要素試験の結果につ いて述べる。

\section{2. ファン空力設計}

ATR に適合し高圧力比化を達成するため，本研究におい ては，以下の方針に基づきファンの設計を実施した .

(1) 圧力比 1.7 の通常の単段ファンに対し, 寸法重量を大 幅に増加することなく, 単段で圧力比 2.2 を達成するた め, ファン動翼にタンデム翼列を採用する .

(2) 本研究で想定する $\left.\mathrm{ATR}^{2}\right)$ の場合, ファンに吸込み空 気を導く 2 本のインテークダクトが複雑な曲りダクト形 状となっている．弚の上, 飛行姿勢等によってファン入口 ではディストーションが発生し易い条件になるため，入 口流れを整流する目的で入口案内翼 (Inlet Guide Vane: IGV) を設ける。

(3) タンデム動翼を出た流れは, 強い旋回カ残るため, ファ ン下流のラム燃焼器への流入スワールを除去するために， 静翼に加えて出口案内翼 (Outlet Guide Vane: OGV) を設ける。

タンデム翼列の概念を第 1 図に示す . 1 枚の動翼から構 成される通常の翼列に対し, タンデム翼列は前翼と後翼の 2 枚から構成される. 動翼への相対流入速度が音速を超え る遷音速ファンでは，隣接する翼の前縁から翼の負圧面に かけて衝撃波が発生し, 翼面の境界層と干渉することでは く離が生じる. 弚れに対して, タンデム翼列では前後の翼 の間隙から，流れを吹出すことではく離を抑制する。こう 


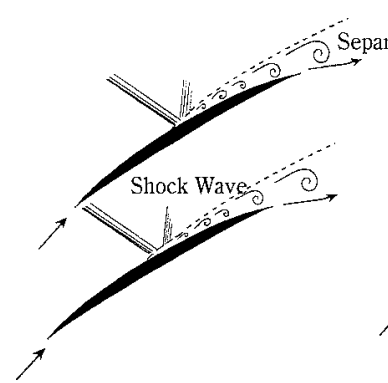

$\triangle$ Conventional Blade

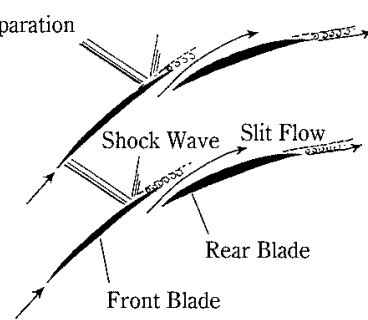

$\triangle$ Tandem Blade

第1図 タンデム翼列概念図

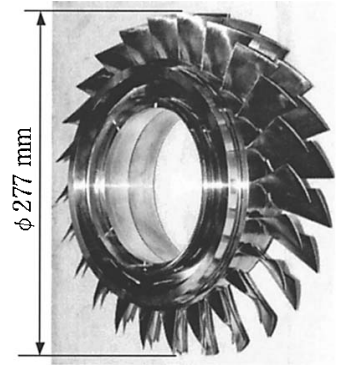

第 2 図タンデム翼列ファン外観図

して, 効率の低下を防ぎつつ高負荷化が可能になる．通常 の遷音速翼列では，効率を維持しつつ負荷を高めても，1 段当りの圧力比は 1.8 程度が限界であった．しかしながら， タンデム翼列を採用することで, 圧力比を 2.2 に向上させ ることが可能となる. 本研究で使用したタンデム翼列ファ ンを第 2 図に示す.

本研究における，ファン要素の構成を第 3 図に示す. 設 計にあたっては, まず流路形状および各翼列の速度三角形 を定め, 谷の後翼形状を設計する. 本研究でのファン要素 は, 動翼, 静翼ともに流入マッハ数が高くかつ高負荷であ る. 弚のため, 流路形状および速度三角形の設計において は, 動翼, 静翼の流入マッハ数をできるだけ低く抑えなが ら , 所定の圧力比が得られるように各翼列への負荷配分を 考慮した。

空力設計にあたっては, まず準三次元流線曲率法による フローパターン計算を行い, 流路形状および各翼前後の速 度三角形を定めた . タンデム翼列については, 前翼と後翼 を光れ光れ独立した翼列として取り扱う.フローパターン 計算では, 翼列の圧力損失を与える必要があるため, 別途 取得した翼列試験データに基づく損失パラメーターを用い た、つまり，二次元翼列の風洞試験を実施し，流入マッハ 数, 流入角に対する圧力損失, 流出角の特性を取得した。 光して, 各翼への流入マッハ数, 負荷配分を最適化してフ ローパターンを決定した . 翼負荷は, 入口案内翼を除く全 翼列に対しほぼ均等に配分した . ディフュージョンファク ターは, 0.5 以下に抑えることで, 翼素性能の劣化を抑えつ つ高圧力比化を図った . また, 動翼の先端流入マッハ数は 1.4 以下とし，衝撃波損失が過大にならないよう考慮した．

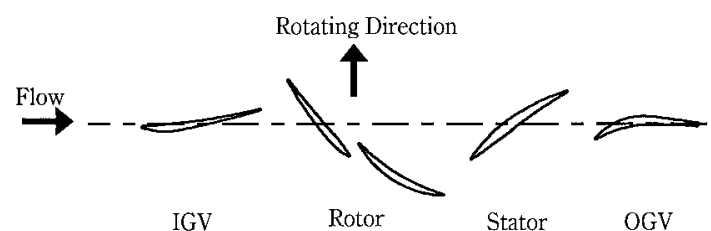

第 3 図 ファン要素の構成

第 1 表 ファン主要諸元

\begin{tabular}{ll} 
Corrected fan speed & $29,700 \mathrm{rpm}$ \\
Corrected air flow rate & $7.03 \mathrm{~kg} / \mathrm{s}$ \\
Pressure ratio & 2.2 \\
Adiabatic efficiency & $80 \%$ \\
Number of stages & 1 \\
Number of blades & $23 / 24 / 31 / 31$ \\
$\quad$ IGV/rotor/stator/OGV) & \\
Tip diameter & $277 \mathrm{~mm}$ \\
Inlet radius ratio & 0.613 \\
Aspect ratio (front/rear) & $1.66 / 1.31$ \\
Solidity (front/rear) & $1.00 / 1.01$ \\
Thickness ratio (front/rear) & $0.077 / 0.078$ \\
\hline
\end{tabular}

その後, 得られたフローパターンに適合する翼形状を設 計する . 流入マッハ数の高い動翼およひ静翼に対しては , 遷 音速域で損失の低い多重円弧翼を初期形状として，流れ解 析および強度解析を実施し, 翼形状調整の繰り返しにより 最適な形状を定めた . 入口案内翼と出口案内翼は, 亜音速 域で作動範囲の広い拡散制御翼を初期形状として，同樣に 翼形状調整を繰り返して形状の最適化を行った . タンデム 翼列においては，三次元粘性流れ解析により翼間流れを解 析し, 前後翼の間隙幅の最適化を行った . 設計したファン の主要諸元を第 1 表に示す.また, 各翼の形状は第 3 図に 示す.

\section{3. 試験装置および方法}

3.1 試験装置 第 4 図にファン試験装置の概要図を示 す．供試体は，増速機を介して電動機により駆動される．供 試体下流に出口主弁, 緊急放風弁か設置されている．出口 主弁はファン作動線を変化させるために使用する．緊急放 風弁は，サージ突入を速やかに回避するために使用する． また , ベルマウス , 入口ダクト等を交換することで, ファ ンへの流入形態を変更した試験が可能となる．第 4 図 (b) , (c) に上方から見た場合の前方流入形態および側方流入形 態でのインレットダクトの樣子を示す .

3.2 試験方法 試験は, 各回転数で出口主弁により流 入流量を調整し，ファン作動点を変化させ性能特性マップ を取得する . まず, ファンの基本的な空力特性を確認する ため, 入口が一樣流入になる前方流入形態で試験を実施し た .つまり，エンジンインレットダクト形状の影響を受け ない状態で, ファン単体性能を取得した . 兴の後, ファン上 流のインレットダクトを実際のエンジン形態と同一な側方 流入形態で , 入口のディストーションを模擬した状態での ファン特性を取得した . 計測は第 5 図に示す各ステーショ 


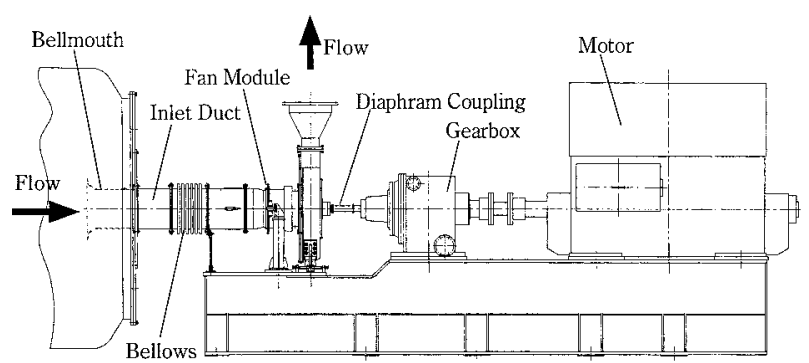

(a) 側方図

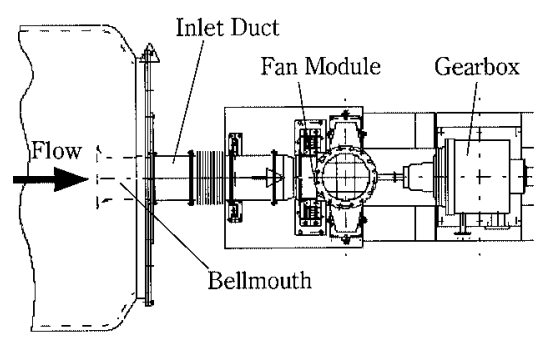

(b) 上方図 (前方流入形態)

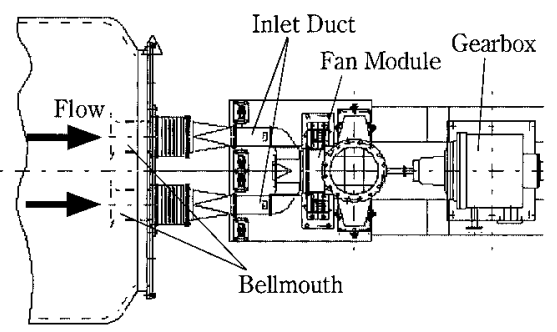

(c) 上方図 (側方流入形態)

第 4 図 ファン試験装置概要図

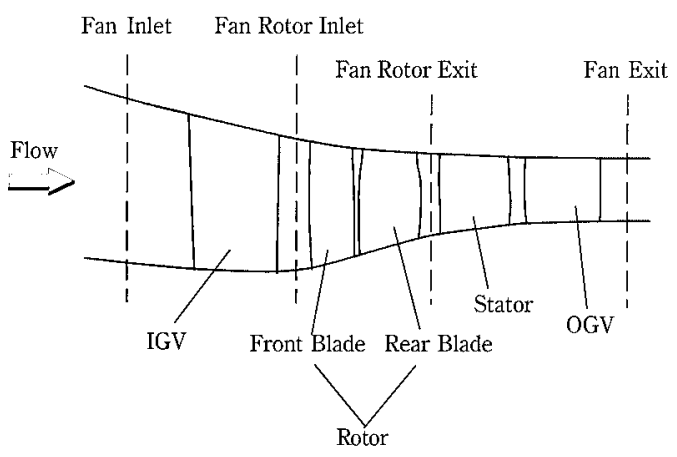

第 5 图 ファン要素各ステーション位置

ンにおいて実施した .

\section{4. 試験結果および考察}

4.1 全体性能 ファン全体特性を得るため, ファン入口 およびファン出口で, レイクプローブを取り付け , 全圧お よび全温を計測した . 性能評価にはファン入口では半径方 向 5 点, ファン出口では半径方向 3 点の平均を使用した. 半径方向分布を調べるために, ファン出口では 3 孔プロー ブ, 全温プローブを使用し全圧, 全温および流出角の半径 方向分布をトラバース計測で実施した .さらに, ウェーク レイクプローブを使用し, 出口案内翼下流の周方向全圧分
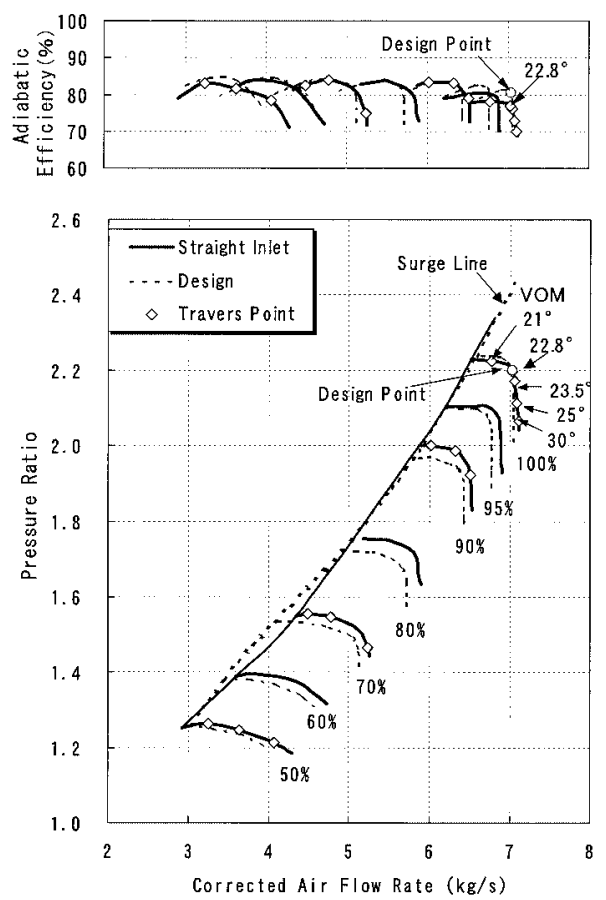

第 6 図 ファン全体特性マップ (前方流入形態)

布を計測した . 第 6 図に前方流入形態におけるファン全体 性能マップを示す．図中のサージ線は，実際にサージに突 入させて確認したものである.また，100\%回転速度におい ては, 5 種類の出口主弁のバルブ開度でトラバース計測を 実施した，定格点に相当するバルブ開度 $22.8^{\circ}$ では, 圧力 比は 2.2 , 断熱効率は $77 \%$ という結果になった . 定格点性 能は, 修正流量 , 圧力比とも設計結果とよく一致している. しかし，断熱効率は設計での予測に対して $3 \%$ 低い結果と なった . この低下の原因については, 後で示す翼素性能で の結果に基づいて述べる.一方，低中回転数域の性能につ いては, 圧力比は設計を上回っている．また効率は, 設計 とほぼ同じ結果であった .サージ余裕については, 特に低 回転数域では設計よりやや少ない結果となった .

側方流入形態試験では, エンジン搭載時と同樣なファン 入口流れを再現し性能を取得する . 側方流入形態での計測 は, ファン入口 , ファン出口にレイクプローブを取り付け， 全圧および全温を計測した 。側方流入形態では，インレッ トダクトによる偏流の影響で, 周方向に全圧分布が生じる ぞのため,インレットダクト上流の全圧計測值からインレッ トダクト部の圧力損失を考慮し, ファン入口全圧を算出し た . 第 7 图にファン入口での全圧分布を示す . 図中の計測 位置角度は，後方から見て時計回りを正としている．入口 全圧は全体に大きな分布はないが, 水平位置である $90^{\circ}$ の 計測位置において , チップ側にやや全圧の低い場所が存在 している.第 8 図に側方流入形態でのファン全体性能マッ プを示す . 前方流入形態での結果と比較すると, 、ップは少 し低流量側に移動している。これは流入形態の違いにより 生じた , ディストーションの影響を受けたためである.しか しながら ,ディストーションの程度は小さく, 流入形態の違 
第 2 表 ファン動翼および全体性能の比較

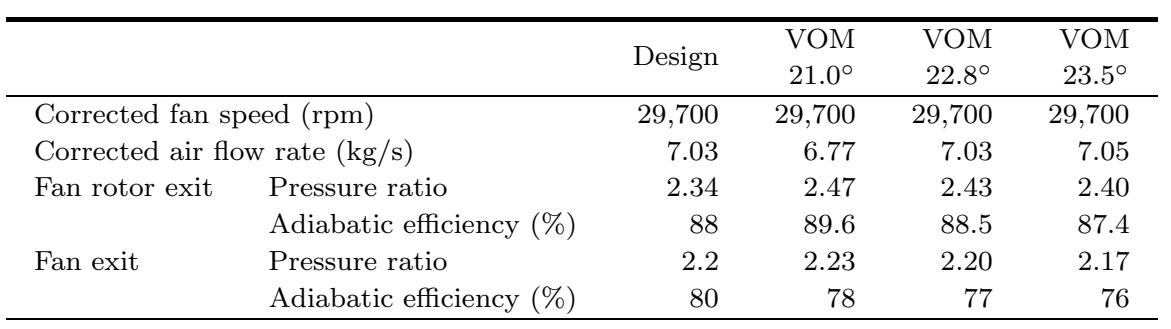

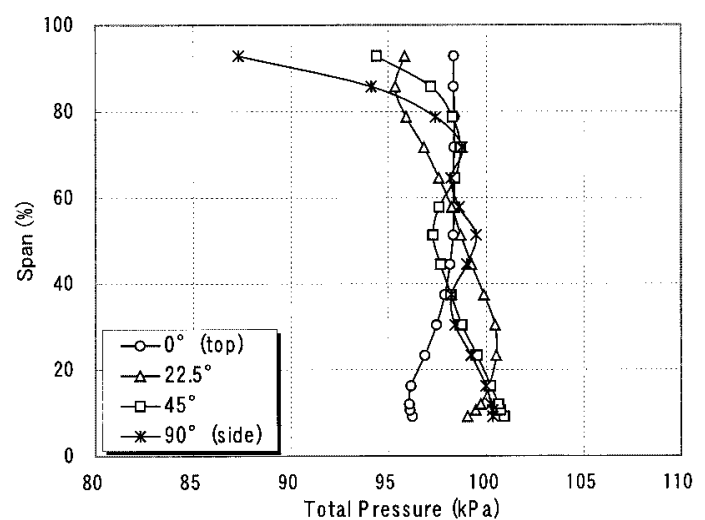

第7図 ファン入口全圧分布
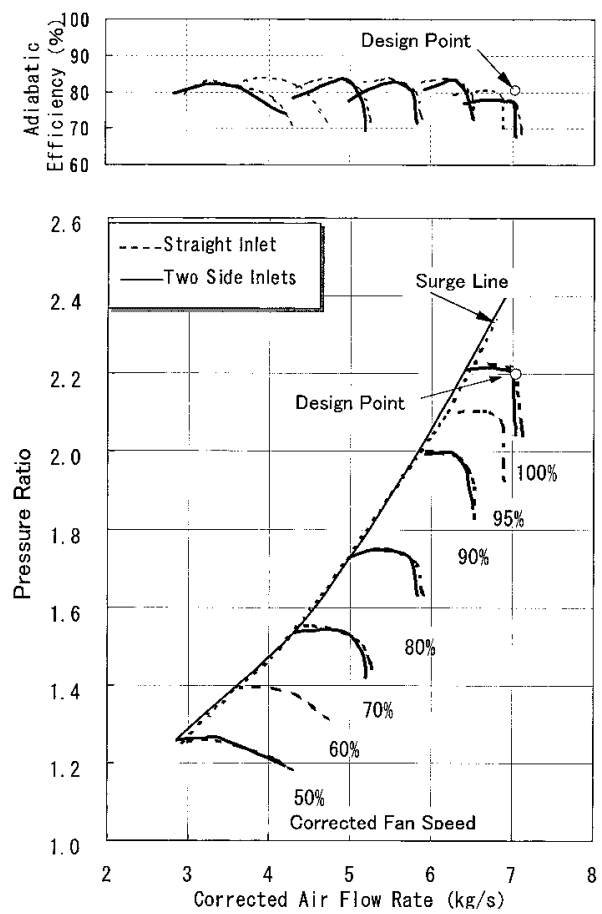

第 8 図 ファン全体特性マップ (前方流入形態と側方流入形態の比較)

いが全体性能に，ほとんど影響を及ぼさない結果となった．

4.2 翼素性能 ファン動翼出口およびファン出口でそ れどれトラバース計測したデータをもとに, 動翼系 (タン デム動翼) と静翼系 (静翼 + 出口案内翼) の二つの翼列 要素に分離し, 翼素性能を評価する . ファン動翼出口では 3 孔プローブをトラバースし計測した . ファン出口では 3

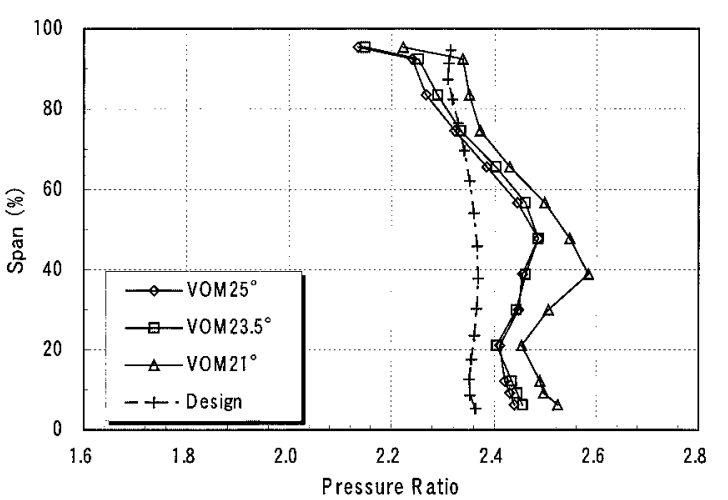

第 9 图 ファン動翼出口圧力比分布

孔プローブ, 全温プローブをトラバースして計測を実施し た . 翼素性能評価のためには, 動翼系と静翼系の入口, 出 ロステーションでの状態量分布を求める必要がある. 并こ で, ファン動翼入口では, 入口案内翼の負荷が小さいこと から設計どおりの圧力損失係数, 流出角としてファン動翼 入口分布を求めた . ファン動翼出口では , 全圧と流れ角は 計測値を使用した . また, 温度分布は, ファン出口と同樣 と仮定した . ファン出口では, 全圧, 全温, 流れ角の計測 值を使用した .これらの値を使用し，準三次元流線曲率法 で各ステーションでの半径方向分布を求め, 翼素性能を評 価した .

ファン動翼 , 全体性能の試験結果と設計結果との比較を 第 2 表に示す . ファン動翼系の試験結果は, ファン入口か らファン動翼出口のものである . 表中の VOM は , 供試体 下流に設けた背圧調整のための出口主弁のバルブ開度であ る.VOM の值が小さいほど絞り側 (サージ側) にあるこ とを示す. VOM $22.8^{\circ}$ は, 定格点に相当する .この絞り角 において , ファン動翼出口ではトラバース計測を実施して いない. そのため, ファン動翼出口の值は, 近い絞り角の 試験結果より補間して求めている．表より圧力比は設計結 果より高くなっており，断熱効率に関しては，ほぼ設計ど おりである . ファン動翼出口の圧力比および断熱効率の半 径方向分布を第 9 図, 第 10 図に光れ光れ示す. 第 9 図よ り圧力比は, チップ側で設計值とほぼ同レベルであること が確認できる . 一方, 翼のスパン中央からハブにかけては, 設計値に対して高くなっている. 第 11 図にファン動翼出口 の相対流れ角分布を示す. 動翼の流出角はスパン中央から ハブにかけて設計値より小さくなっている .これは , ハブ 側ではより転向角が大きくなって, 高い圧力比が得られて 


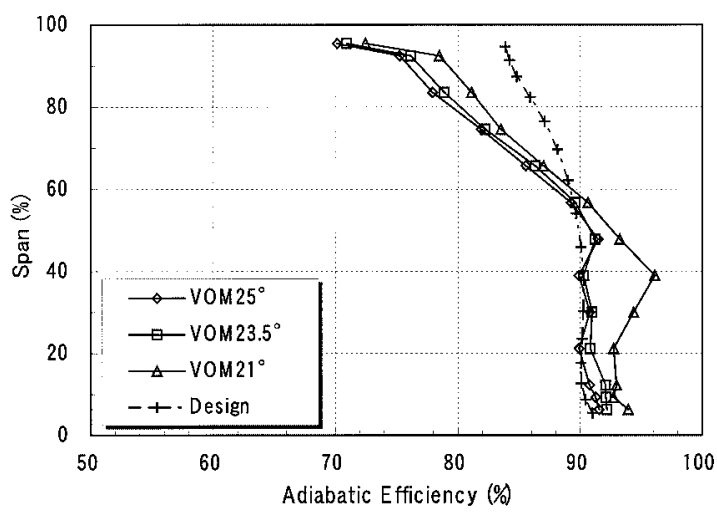

第 10 図 ファン動翼出口断熱効率分布

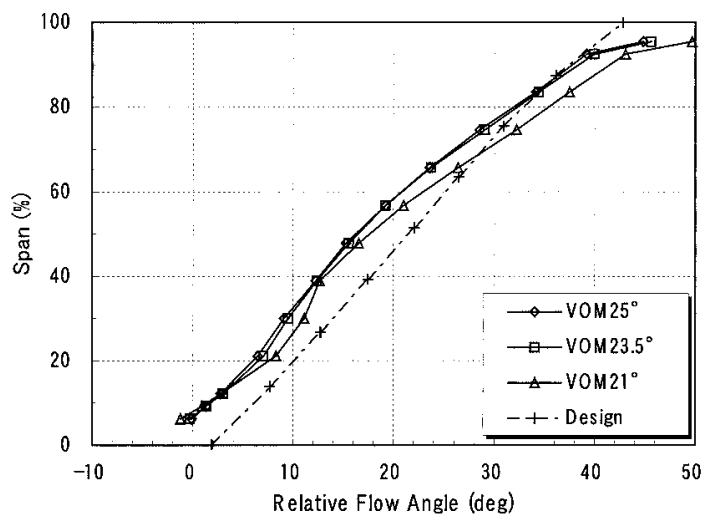

第 11 図 ファン動翼出口相対流れ角分布

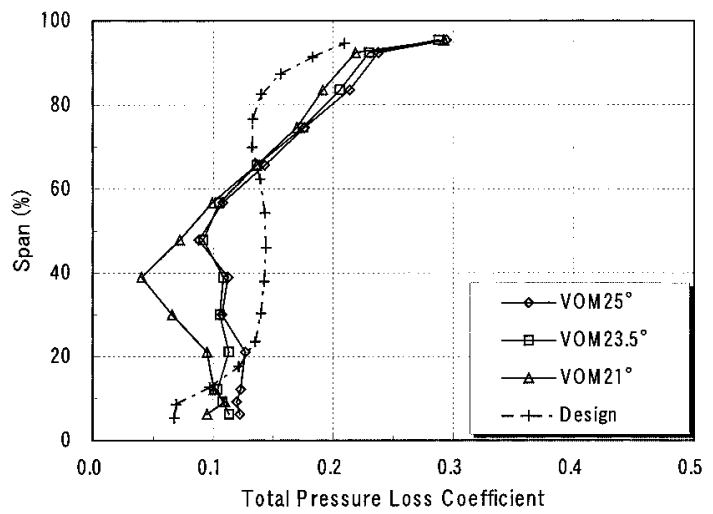

第 12 图 ファン動翼全圧損失係数分布

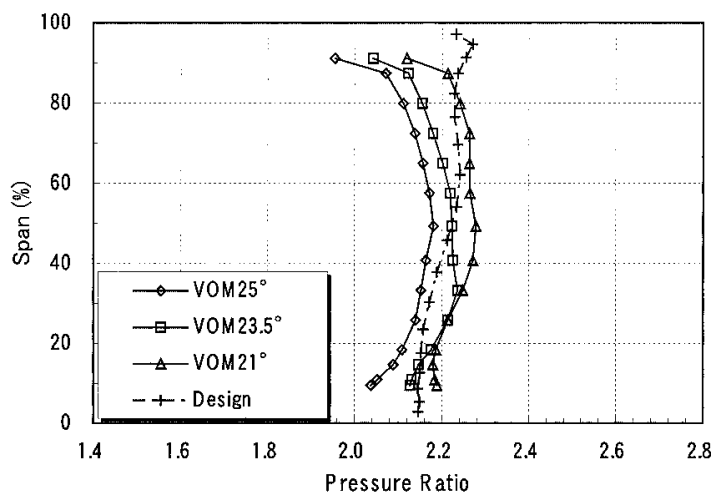

第 13 図 ファン出口圧力比分布

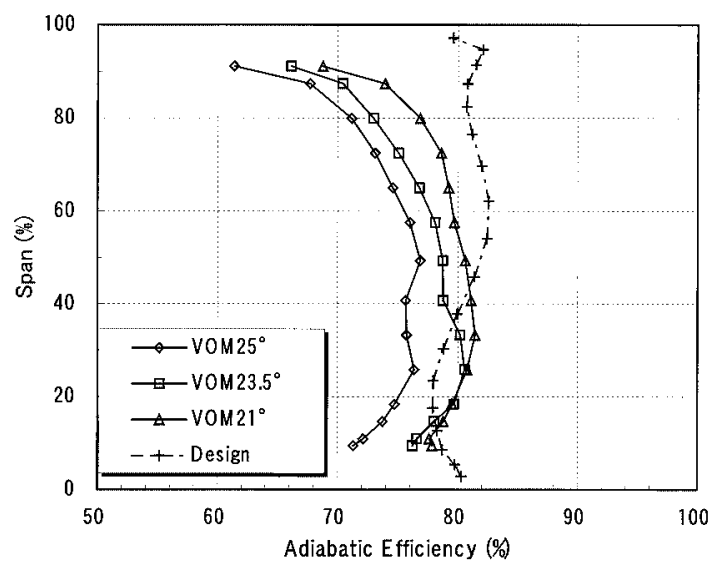

第 14 図 ファン出口断熱効率分布

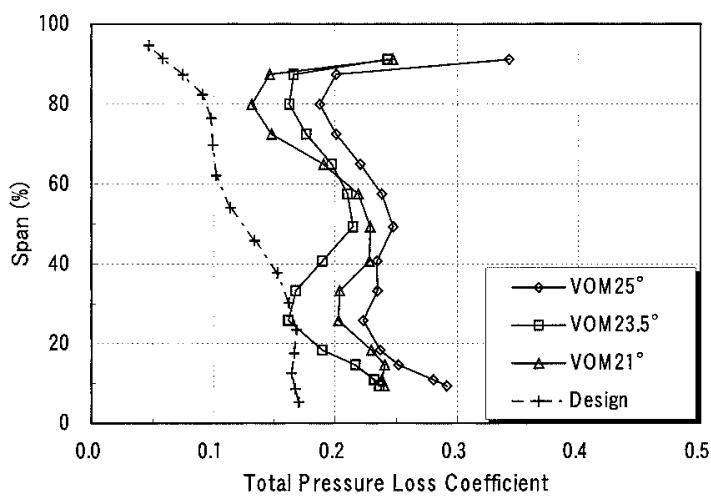

第 15 図 静翼系全圧損失係数分布
いることを示す .このハブ側の圧力比の上昇が，全体とし て設計より高い圧力比になった原因である．一方，断熱効 率については, 第 10 図より圧力比と同樣にハブ側が高く， チップ側で低い分布になっている.これは, 第 12 図に示す ファン動翼全圧損失係数分布より, 動翼チップ側で設計よ り大きな損失が生じているためである．しかしながら，効 率は全体としては, 設計と同レベルになっていることが確 認できる .

静翼系として，第 13 図および第 14 図にファン出口の圧 力比, 断熱効率の半径方向分布を示す. 圧力比, 効率とも にハブ側では設計より高めであるが, チップ側では低めの
値になっている .これは, ファン動翼出口の分布が , ファン 出口にも影響しているためである．また，第 2 表よりファ ン出口で比較した場合，圧力比はほぼ設計と同等で，断熱 効率は設計に対して $3 \%$ 低下している。しかしながら，ファ ン動翼出口で比較した場合，圧力比は設計值より高く, 効 率は設計値との差がほとんどあらわれていない . これより， 静翼系で設計よりも全圧が低下しているために, 全体とし ての効率低下を引き起こしていることがわかる.第 15 図 に静翼系の全圧損失係数を示す.いずれのスパン位置にお いても，設計に比較し大きな損失が発生している．つまり， 静翼を含む全体圧力比が低下するのは, 主に静翼の損失が 


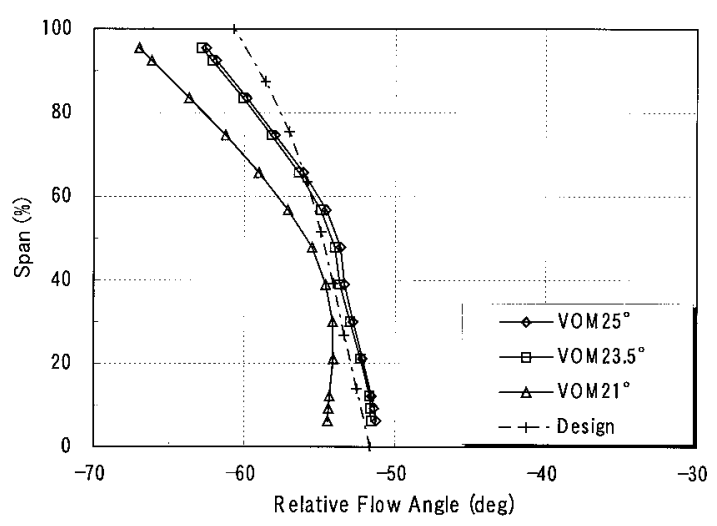

第 16 図 静翼入口流れ角分布

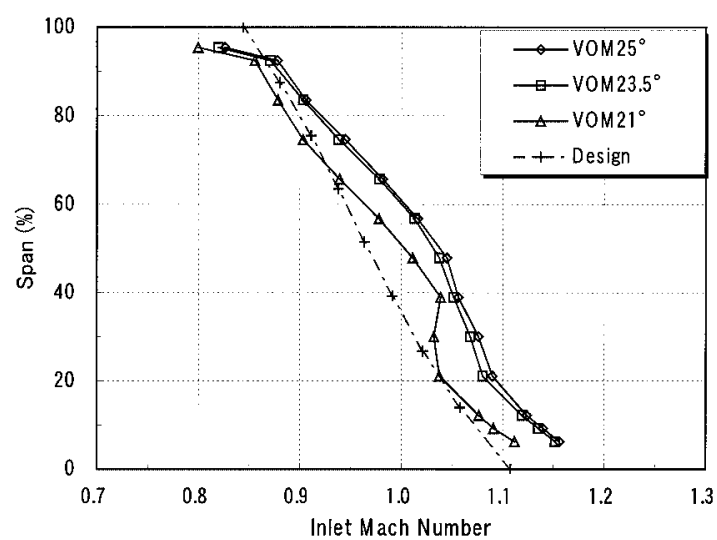

第 17 図 静翼流入マッハ数分布

増大しているためである．

また，第 16 図に静翼入口での流れ角分布を示す . 流れ 角は, チップ付近で一部設計に対して過大になっているが， 中央およびハブではほほ設計どおりである．これより静翼 に対するインシデンスは，適正でると考えられる.第 17 図 に静翼への流入マッハ数の分布を示す．八ブ側で特に, 設 計值より流入マッハ数が大きくなっている．つまり主とし
て, 静翼への流入マッハ数が高く, 静翼での衝撃波損失が 増大したことが，静翼での損失を増大している．これより， 静翼系において設計より圧力損失が過大であることが, 設 計值に対してファン全体の効率が低くなった原因である .

\section{5. 結言}

ATR に適用しエンジンの高推力化を達成するために , タ ンデム翼列を適用しファンの高負荷化を行った . タンデム 翼列を動翼に使用したファンを設計，製作し要素試験によ り空力性能を確認した，乥の結果，効率を維持しつつ単段 で圧力比 2.2 を達成できた。 .また，現在 ATR エンジン形 態として想定している側方流入形態 2 本インテークの場合 における，ファン性能を取得した . 想定している側方流入 形態においてのファン空力特性は, 基本性能に対してほと んど影響を及ぼさないことが確認できた .

今後は, 飛行状態で発生するディストーションを模擬し た状態でのファン空力性能について，確認を実施する予定 である .

\section{参 考 文 献}

1) Nicholas, D. J. and Freeman, C.: Recent Advances in the Performance of High Bypass Ratio Fans, ICAS-82-4.1.3, 1982.

2) 長谷川裕晃, 北原一起, 犬飼保夫 : 小型・高推カエアーターボラ ムエンジン, 日本航空宇宙学会論文集 , 50 (2002), pp. 272-277.

3) Lilley, J. S., Hecht, S. E., Kirkham, B. G. and Eadon, C. A.: Experimental Evaluation of an Air Turbo Ramjet, Proc. 30th AIAA/ASME/SAM/ASEE Joint Propulsion Conf., Indianapolis, IN, AIAA Paper 94-3386, 1994.

4) Bossard, J. A., Christensen, K. L. and Poth, G. E.: ATR Propulsion System Design and Vehicle Integration, Proc. 24th AIAA/ASME/SAE/ASEE Joint Propulsion Conf., Boston, Massachusetts, AIAA Paper 88-3071, 1988.

5) Bammert, K. and Beelte, H.: Investigations of an Axial Flow Compressor with Tandem Cascades, J. Eng. Power, 102 (1980), pp. 971-977.

6) Bammert, K. and Staude, R.: Optimization for Rotor Blade of Tandem Design for Axial Flow Compressor, ASME 79GT-125, 1979. 